Chodziński, M. (2019). The tendency of households to invest in an ecological modernization of the utilized heating sources. Copernican Journal of Finance \& Accounting, 8(1), 27-58. http://dx.doi. org/10.12775/CJFA.2019.002

\author{
Maciej Chodziński* \\ Nicolaus Copernicus University in Toruń
}

\title{
THE TENDENCY OF HOUSEHOLDS TO INVEST \\ IN AN ECOLOGICAL MODERNIZATION \\ OF THE UTILIZED HEATING SOURCES
}

Keywords: investments, corporate social responsibility, smog, heating, ecology, household finances.

\section{J E L Classification: Q57.}

\begin{abstract}
The aim of the article is to determine the impact of economic aspects on the decision-making process on modernization of heating sources used by households in the largest cities of the Kuyavian-Pomeranian Voivodeship. Excessive use of obsolete and worn out heating sources contributes significantly to intensive air pollution, especially during the winter season. The article uses a questionnaire survey carried out in the form of an online survey, addressed to the residents of Bydgoszcz, Torun and the surrounding area. The survey was conducted using the google form, which was sent to random users of social networks. The form was also published on groups associating residents of Bydgoszcz and Toruń, as well as student groups of these cities. As a result of the survey we managed to obtain 153 correctly filled questionnaires. The analysis was based mainly on the analysis of the frequency of responses given and the analysis of correlations. Because of this analysis, it can be concluded that the decisions related to the choice of the type of a new heating source and its level of environmental performance are mainly related to economic aspects, not over-care for the natural environ-
\end{abstract}

Date of submission: March 8, 2019; date of acceptance: April 14, 2019.

* Contact information: 267037@doktorant.umk.pl, Faculty of Economic Sciences and Management, Nicolaus Copernicus University in Toruń, Gagarina 13a, 87-100 Toruń, Poland, phone: +48 508870 649; ORCID ID: https://orcid.org/0000-0001-72457833. 
ment. A large proportion of respondents believe that they are willing to allocate an additional sum of money to the planned purchase only due to ecological values, however a large part of them declares sums that are really too small to translate into a more environmentally friendly product. It means that for the surveyed the main group of factors affecting the selection of the heating source are economic factors, and the added value which is less emission of harmful pollutants often goes to the background (although it is not completely insignificant). It results from the fact that ongoing subsidy programs are the most effective form of improving the situation, however, the level of funding should bring the price of ecological furnaces closer to their traditional, cheaper counterparts.

\section{IIIINTRODUCTION}

It is spoken a lot of about a green development with the respect to the popularity and the common fashion for ecology, however, it is often associated with superficial actions entailing noticeable changes. The superficiality is attributed to a large number of introduced solutions, for instance to the reports of social responsibility for business. However, a little attention is paid to the decision taken by ordinary people. All fundamental changes shouldn't have roots in the actions of big firms, corporations, enterprisers or countries but in the behaviour of ordinary people because these are people who create and manage all economic structures existing in economy, so that in people lies the biggest power determining all changes (www1).

An excellent experimental area in recognizing people's attitude to problems and ecological challenges of the contemporary times can be the most popular for a few years - the problem of polluted air in Poland, increasing in the winter time. This phenomenon concerns mostly the municipal and suburban areas and its source is fuel used for heating households and buildings. Taking into consideration the above circumstances, the tendency to invest in modernization of utilized heating sources has become the basis to write the below article.

\section{THE RESEARCH METHODOLOGY AND THE COURSE OF THE RESEARCH PROCESS}

In this article there have been used the research methods including: the critical analysis of literature, the analysis of market data, as well as the survey research, completed in the form of the Internet questionnaire made up with the use of Google application form consisting of 14 questions. This form was directed to the groups consociating on the social networks the dwellers of the biggest 
cities of kujawsko-pomorskie voivodeship which are Bydgoszcz and Torun and also their neighborhoods. The surveyed respondents replied in the period of $8-20^{\text {th }}$ December 2018. In such a way, a gathered research data was afterwards submitted to a statistical analysis with the use of SPSS Statistics and Microsoft Excel programmes.

\section{THE PROBLEM OF AIR POLLUTION IN POLAND}

The problem of air pollution has been in the last years one of the most popular issues, arising in different kinds of media in Poland, especially in the autumnwinter time. A gradually decreasing air temperature made a large number of dwellers heat their houses more intensively. An increased exploitation of furnaces is associated with an increased emission of combustion products into the atmosphere, which collects contamination mainly in the form of dust suspended PM 2.5 and PM 10, and also toxic gases such as nitric oxide, sulphur dioxide, hydrogen chloride or hydrogen fluoride (www2).

One of the most harmful combustion products is benzoapyrene - polycyclic aromatic hydrocarbon which affects particularly badly a human body, for example, by: adrenalopathy, lymphatic disorder, respiratory diseases and also the increase of cardiovascular diseases. In Poland the benzoapyrene concentration is one of the highest in Europe, which is presented on the visual map on the scheme 1.

One of the main causes of the bad air condition in Poland is the emission of the harmful substances arisen as the result of households heating with lowquality fuel (or even toxic waste which should be utilized in specialized companies). Additionally, low-quality fuel is often associated with highly ineffective furnaces which while working achieve low efficiency in transformation of incinerated fuel into thermal energy, which additionally increases the use of utilized feedstock and the level of emitted pollutants (www2).

However, this problem doesn't only concern Poland, it is also widely noticed in other countries such as China which have considerable difficulties in an effective fight with so called smog. In such a case, the effect of a gradual improvement is achieved mainly by the severe restriction of Chinese government dealing with the reduction of the amount of carbon incinerated by the industry (www3). 
Scheme 1. The benzoapyrene concentration in selected countries in 2014
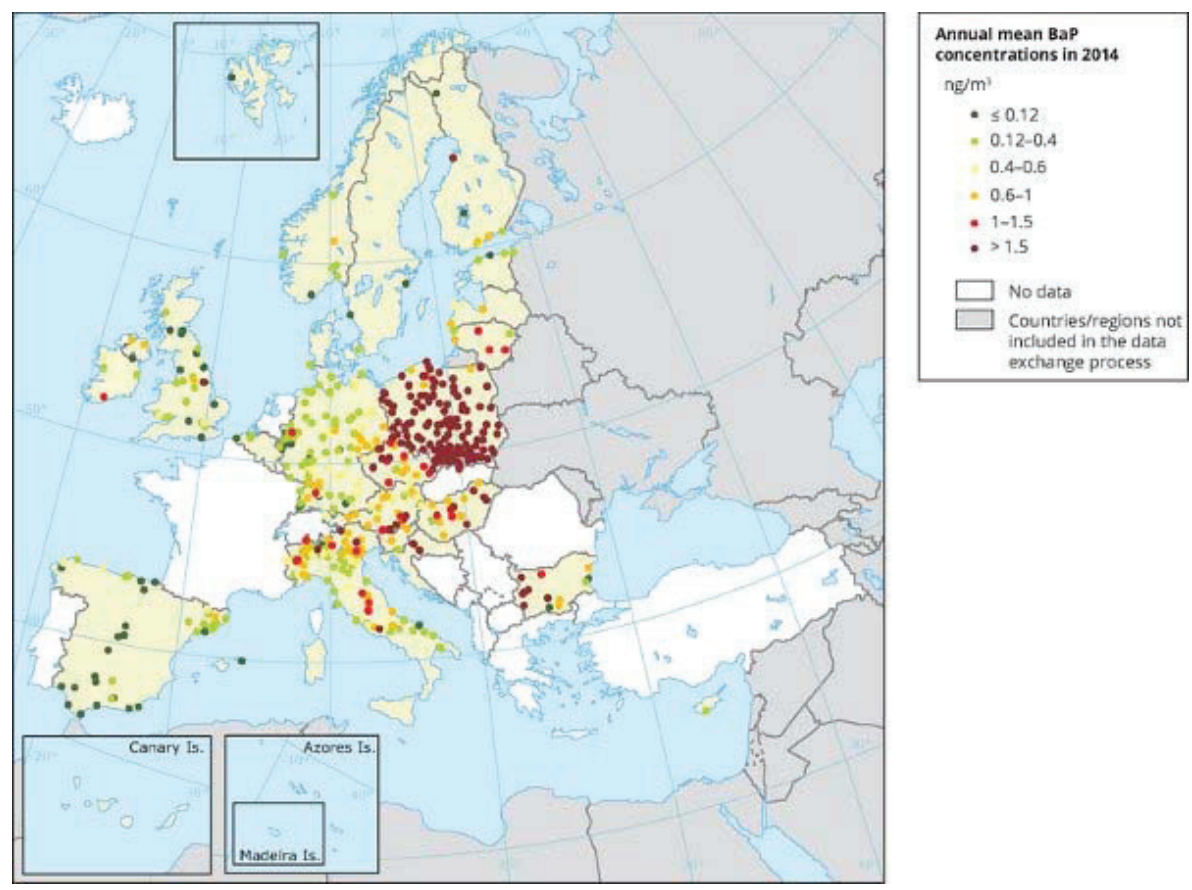

S o u r ce : (www6).

In Poland, the main reason for the formation of smog is the so-called low emission. It is the emission of combustion products into the atmosphere from chimney outlets located up to 40 meters above ground level. Such a low height means that the products of combustion along with contaminants stay close to the ground, where they are inhaled by respiratory systems of humans and animals. For this reason, the basic ad hoc preventive measure that protects the health of urban residents is personal air filters in the form of dust masks or gas masks with more advanced, multi-stage pollution filtration systems (Mikłaszewski, 2017, pp. 6, 20).

One of the cities struggling with the largest air pollution in Poland is Kraków. In this case, the conducted research shows that the main part of low emission pollution is generated both in the scale of the Małopolskie Voivodship, as well as on the national scale through the generation of heat in individual or local boiler houses in the winter season. In order to minimize low emissions and an excessive amount of harmful substances, the Małopolskie Voivodeship focus- 
es on comprehensive modernization of households, including not only replacement of obsolete sources of heat, but also thermo-modernization of buildings. Smaller heat losses mean less heating needs and what is associated with this is a smaller amount of burnt coal and other fuels used in heating. Krakow's problems associated with an extremely high amount of pollution affect not only the health and physical condition of the residents. Material property is also threatened, especially historical properties, which are subject to faster degradation as a result of exposure to long-term pollution. Bricks and concrete walls crumble faster, and metal elements are subject to accelerated corrosion, which adversely affects the image of the city both for residents and tourists visiting the former capital of Poland (Kaczmarczyk, 2015, pp. 28-38).

Taking into account the structure of pollution sources from low emissions, it can be clearly stated that households are the biggest culprit. In order to reduce the pollution, they generate the city of Krakow develops alternative heating sources, actively developing the gas network, in addition to the aforementioned thermo-modernization. Other activities focus on other sources of pollution such as private transport or industry. The activities undertaken focus on reducing excessive traffic where it is unnecessary, and replacing the solutions used with more ecological ones (Kaczmarczyk, 2015, pp. 38-49).

An alternative to energy for smaller towns located near large agricultural areas may be, in addition to the previously mentioned sources - biomass heating plants. This fuel is relatively easy to process and use, and its main source may be a shrub willow, collected cyclically once a year (Budzynski \& Bielski, 2006).

Another alternative method of heating may be heat pumps, the use of which for economic reasons becomes more and more profitable. However, the wider application depends to a large extent on the location of a given building and geological conditions (in the case of pumps drawing energy from the ground). The heating power derives from a constant temperature that remains at a certain level below the ground. In the opinion of many, this is a source with high development potential in the future, similar to other renewable energy sources with a low degree of environmental nuisance (Lesniak, Janczar-Smuga, Podgorski \& Klinkowski, 2012).

In addition, new innovative solutions are constantly emerging that allow for obtaining thermal energy, among others using magnetic fields of permanent magnets, however, such solutions are not yet advanced enough to be able to 
estimate their rational and economically efficient use on a wide scale (Nowak \& Kowalczyk, 2015).

A representative of Germany, which is geographically closer to Poland, has been creating the plans of a gradual withdrawal of the conventional sources of energy by renewable energy sources since the nineteens of the previous century. Initially, this concept established the introduction of the minimal rates on wind power, solar energy and the one received from the small generators gaining water-dwelling energy. Gradually, this law had been undergoing modification till 2016 year when there was introduced an act about the renewable energy sources (EEG) which became an example to follow for other countries. Such an act guarantees the priority of the flow of energy from the renewable energy sources and also determines for it a minimal market price. Consequently, the system, which was the guarantor of a high security level of investments into renewable energy sources, was created. At the same time, it confined redundant bureaucracy (Morris \& Pehnt, 2017, pp. 30-31).

In Poland the actions undertaken against the air contamination concentrate mainly on supporting the modernization used by households (considered as the main cause of the problem) the heating devices, as well as the controls of fuel incinerated in them. The expression of the combat with contamination on the local level is, among others, the program of premiums to the modernization of the utilized heating sources, recognized as non-ecological. In accordance with the information of the Bydgoszcz City Council in 2018 as part of the program "EKOpiec 2018" it is possible to receive a bailout of the conducted modernization up to $4000 \mathrm{zl}$. The program covers heating sources powered with solid fuel. The beneficiaries of this support are "owners, co-owners of the properties, representing a single-family residential building or a dwelling, used entirely for one's own housing needs or the users of perpetual real estates on which there is situated a single-family residential building, used entirely for one's own housing estates" (www4).

A little more complex system of premiums has been implemented in Toruń. In this case, the main condition to receive them is to own an old type of a furnace for solid fuel. The amount of money possible to gain in the form of reimbursement is established as a percentage which value cannot exceed $70 \%$. However, most variants fluctuate between $40-60 \%$ of expenditure incurred by an owner of a real estate. In addition, there appear the numerous limitations of maximum amounts which are likely to be gained depending on a concrete 
case (the detailed regulations are not presented here in view of editorial constraints) (www5).

\section{THE TENDENCY OF DOMESTIC HOUSEHOLDS TO INVEST IN THE MODERNIZATION OF UTILIZED HEATING SOURCES - THE SURVEY RESULTS}

Considering the described actions, undertaken on the local level and aiming at the improvement of the air quality, it is worth thinking what it is the tendency of dwellers to carry out the modernization of heating sources? How strongly do local inhabitants appreciate economy, and how - ecology?

For this purpose, a result survey has been conducted, in which 153 respondents participated. The survey consisted of 13 or 14 questions (the number of questions depended on the kind of reply a person gave). All questions were a single choice and replies were given in the Internet application form by means of a computer or a phone.

The first question concerned a kind of building in which a person lives and there were 3 answers to choose. The surveyed responses have been presented on the 1 figure.

Figure 1. A frequency of given replies on a question 1

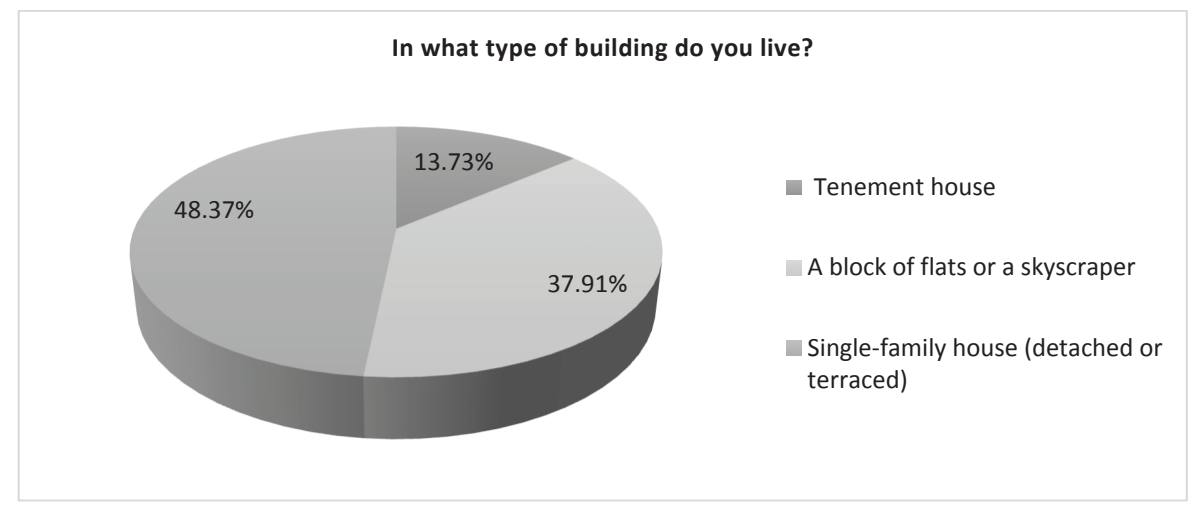

S o u r c e : own elaboration. 
Figure 2. The frequency of responses given on a question 2

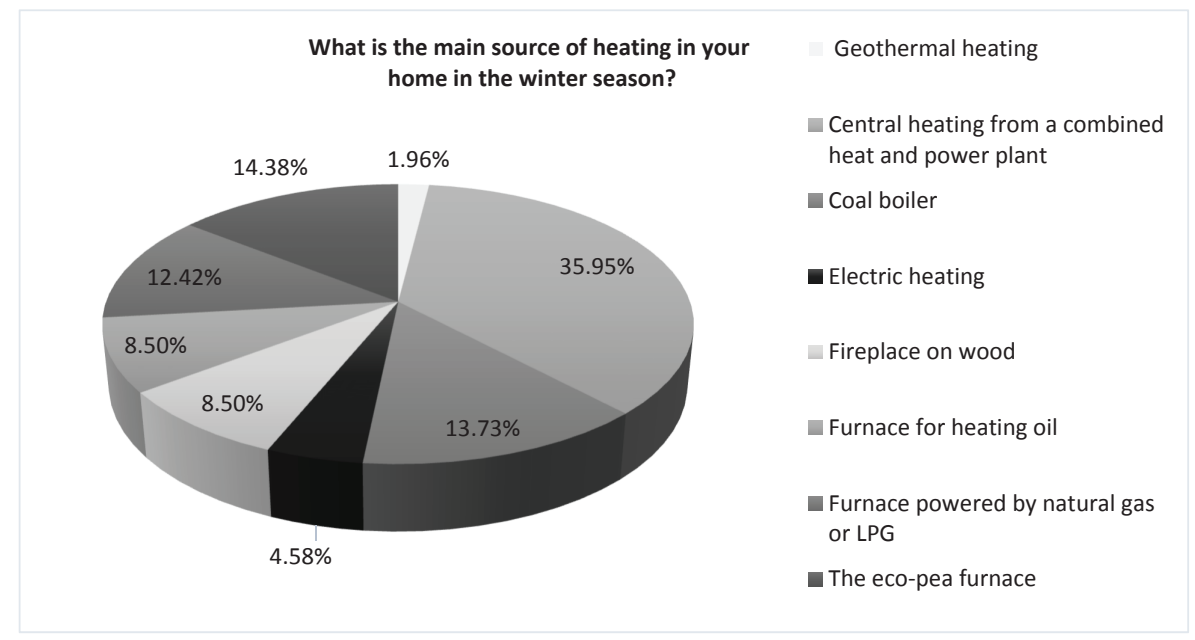

S o u r c e : own elaboration.

In the analysed group nearly $38 \%$ of respondents live in blocks of flats or high- rise buildings, so these are buildings which from the point of view of the mentioned problem are less important because probably most of them are heated by the heat from a municipal electrical power and heating plant. As a result, they do not have influence on the utilized heating source. The other group, however, consist of the dwellers of tenement houses and single-family houses which responses will probably be the main subject of analysis.

The further question (no. 2) concerned the currently used basic heating source in the winter time. In this case there has occurred a remarkable differentiation presented on the figure 2 . 
Figure 3. Frequency of responses on question 2 for the dwellers of block of flats and high rise buildings

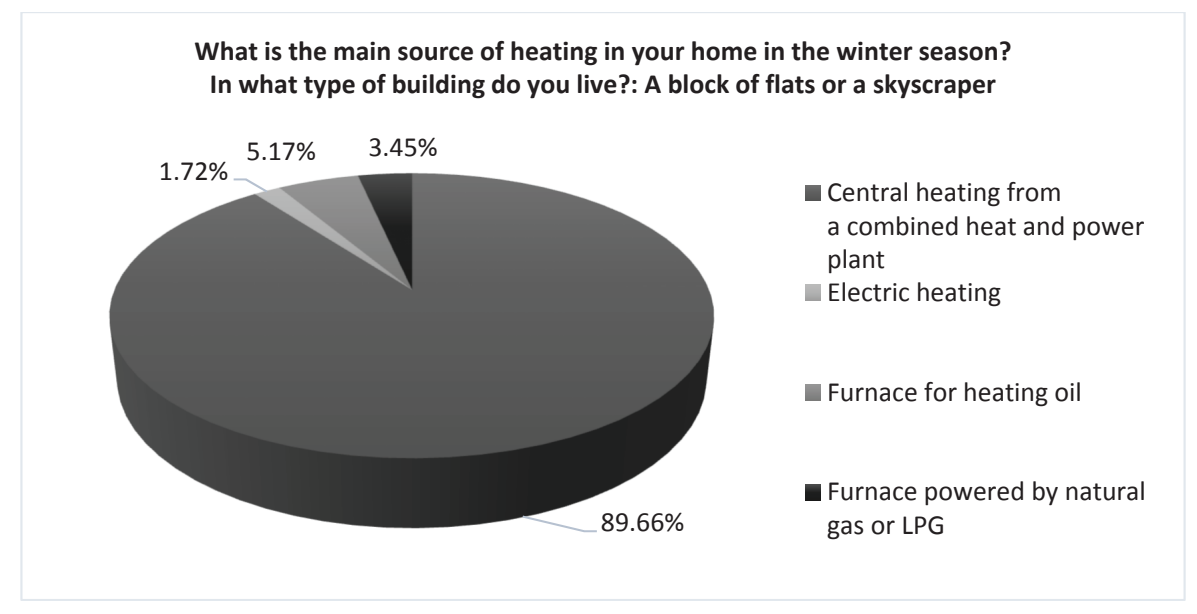

S o u r c e : own elaboration.

In this point, it is worth combining heating source with a place of living. The data structure concerning of the utilized heating source have been presented on the figure 3-5. Concluding from the presented data, in accordance with the suspects, the dwellers of block of flats and high rise blocks only in a small degree (about 10\%) used their own heating sources on which modernization they could have an influence. In case of a single-family house there appears a remarkably bigger differentiation. It is important to mention that over $1 / 4$ houses is still heated by non-ecological coal boilers. In addition, as a consequence of heating fireplaces with wood, there appear about 38\% harmful and ineffective heating sources. The percentage can be even higher because a part of furnaces can be outdated and do not fulfil emission standards. 
Figure 4. The frequency of answers on question 2 for the dwellers of single-family houses

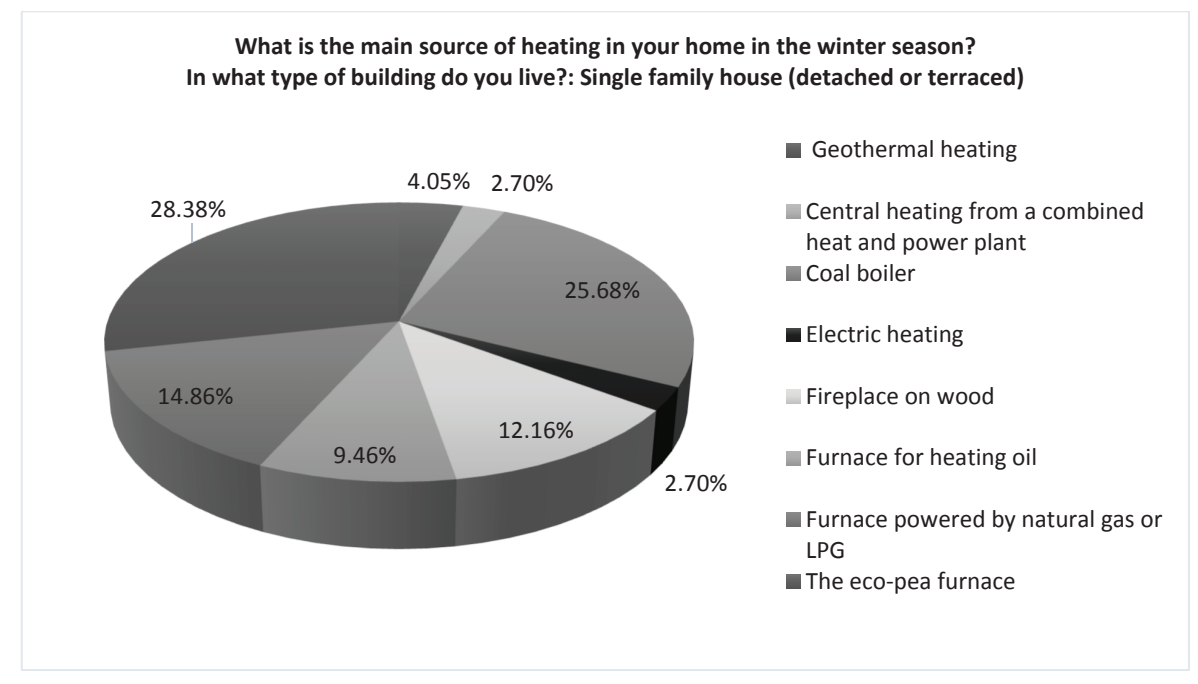

S o u r c e : own elaboration.

Figure 5. The frequency of answers on a question 2 for the dwellers of tenement houses

What is the main source of heating in your home in the winter season? In what type of building do you live?: Tenement house



- Central heating from a combined heat and power plant Coal boiler

Electric heating

Eireplace on wood

Furnace for heating oil

Furnace powered by natural gas or LPG

- The eco-pea furnace

S o u r c e : own elaboration. 
Figure 6. Frequencies of answers to question 3 depending on the place of residence

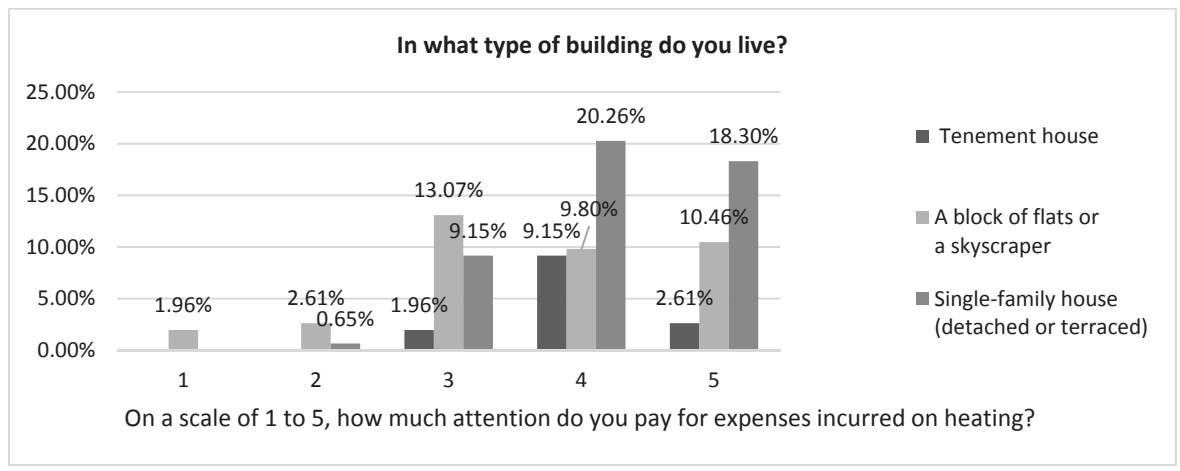

S o u r c e : own elaboration.

Question 3 concerned the subjective assessment of the respondent, about how much importance he attached to the expenditure for heating (on a scale of 1 to 5). When analyzing the answers, it is worth looking at the obtained data depending on how the respondent answered in question 1 and 2 . The relevant relationships are presented in figure 6 and 7.

First of all, you can notice a clear left side skew of the presented distribution, which takes place regardless of the type of place of residence. It is worth noting that much more expenditures are sought for by residents of houses and tenement houses, that is, buildings in which they themselves decide about the source of heat. These conclusions are also confirmed by the analysis of responses to the available heat sources. People using heating from combined heat and power plants (the most popular in blocks and high-rise buildings) showed some tendency to lower interest in their expenses than other respondents.

Persons who indicated the greatest interest in the expenses incurred are mainly people using central heating. In the second place, there are people using coal boilers and natural gas furnaces (5.88\% of all respondents). The remaining types of furnaces are used by a much smaller number of respondents who chose the answer with a weight of 5 . 
Figure 7. Frequencies of answers to question 3 depending on the heating source

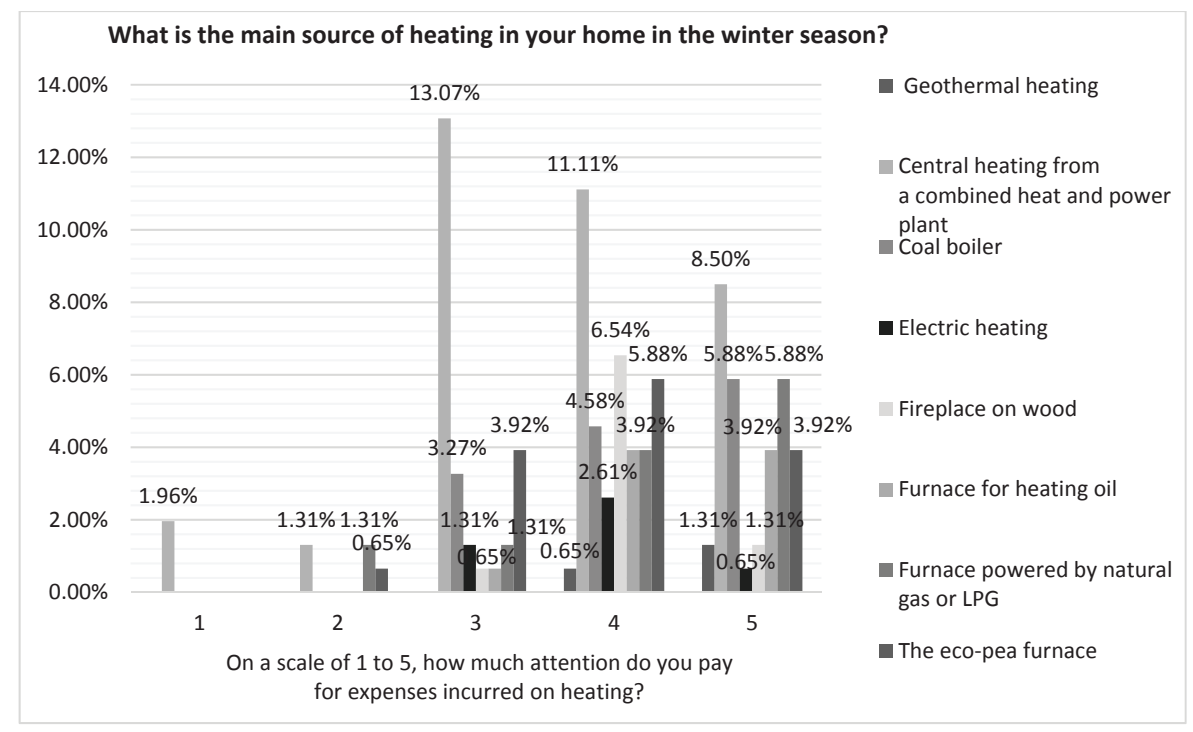

S o u r c e : own elaboration.

Figure 8. Frequencies of answers to question 4 depending on the place of residence

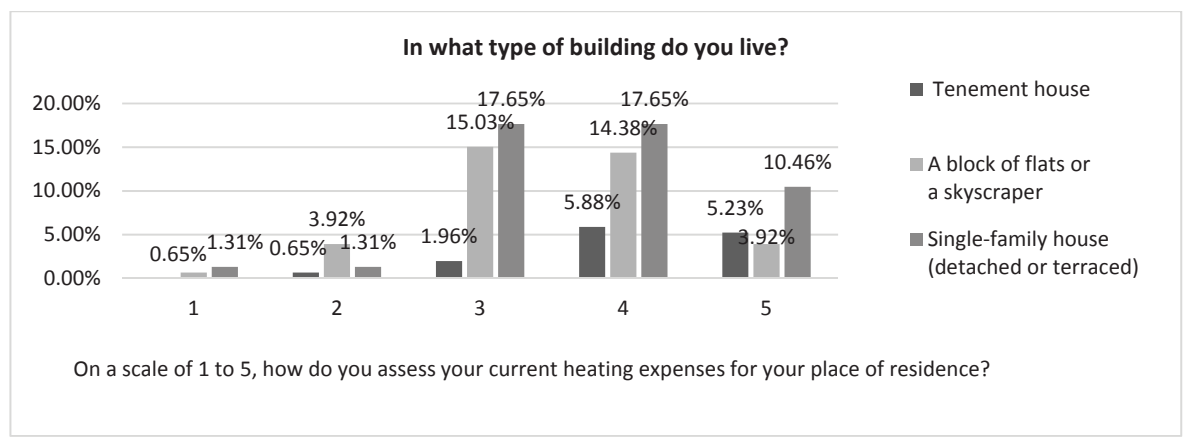

S o u r c e : own elaboration. 
Table 1. Descriptive statistics of the answers from questions 3 and 4

\begin{tabular}{|c|c|c|c|}
\hline & & Question. 3 & Question. 4 \\
\hline \multirow{2}{*}{$\mathbf{N}$} & Significant observations & 153 & 153 \\
\hline & Data shortages & 0 & 0 \\
\hline \multicolumn{2}{|l|}{ Average } & 3.95 & 3.67 \\
\hline \multicolumn{2}{|l|}{ Median } & 4.00 & 4.00 \\
\hline \multicolumn{2}{|l|}{ Dominant } & 4 & 4 \\
\hline \multicolumn{2}{|c|}{ Standard deviation } & .930 & .924 \\
\hline \multicolumn{2}{|l|}{ Skewness } & -.739 & -.368 \\
\hline \multicolumn{2}{|c|}{ Standard error of skewness } & .196 & .196 \\
\hline \multicolumn{2}{|l|}{ Kurtosis } & .476 & .027 \\
\hline \multicolumn{2}{|c|}{ Standard kurtosis error } & .390 & .390 \\
\hline
\end{tabular}

S o u r c e : own elaboration.

Question 4 concerned the assessment on a scale of 1 to 5 of the subjective feeling of the burden of expenses currently incurred. In this case, the distribution of responses is similar to the distribution from question 3 discussed above. With the difference that the observed left skewness of the distribution shows a slightly lower strength. Graphic observations confirm the calculated values of skewness and kurtosis, whose values for questions 3 and 4 are presented in table 1.

In relation to the heat sources owned, the answers were more diversified than in the previous question. Most often, at moderate or high level, people with central heating set their expenses, similarly as in question 3 , such large amounts result from the structure of the surveyed group, about $36 \%$ of respondents lived in blocks and had this type of heating. Among the rest of the respondents at a very high level, most often the owners of coal boilers positioned their expenses (less than $4 \%$ of the total answer, which is about $24 \%$ of all those who considered their expenses very high), and the owners of oil furnaces ranked third. fuel. In case of a high level of expenditure (again excluding people with central heating), the most numerous groups were people who heated with natural gas (5.88\% of total waste), as well as wood burning stoves and eco-pea kiln stoves. Among the heating sources considered to be non-organic in a moderate way, coal boiler owners most often assessed their expens- 
es. Interestingly, almost half of them (about 47\%) consider their expenses to be moderate or low. The owners of fireplaces on wood most definitely estimate their expenses, in their case the high level was most often chosen (about $40 \%$ ), the remaining people considered spending as moderate (about 30\%) or very high (about 15.5\%). Quite a similar distribution of responses as in case of wood-burning fireplace owners occurred among people using gas heating (except that the division between moderate and high expenditures spread evenly), as well as electric heating. In case of heating oil, the responses from moderate to very high levels were on the same level. The dominant feature of people using eco-pea kiln furnaces was moderate (45.48\%), at the high level, $31.85 \%$ of respondents defined their expenditures, and very high - around $18 \%$. What is interesting, however, is the fact that only single people chose the answer from the range of expenses from very low to low. This may result from the treatment of expenses as a "necessary evil", then people who perceive their expenses may have a tendency not to recognize them as low, regardless of the amount they would be.

Figure 9. Frequencies of answers to question 4 depending on the heating source

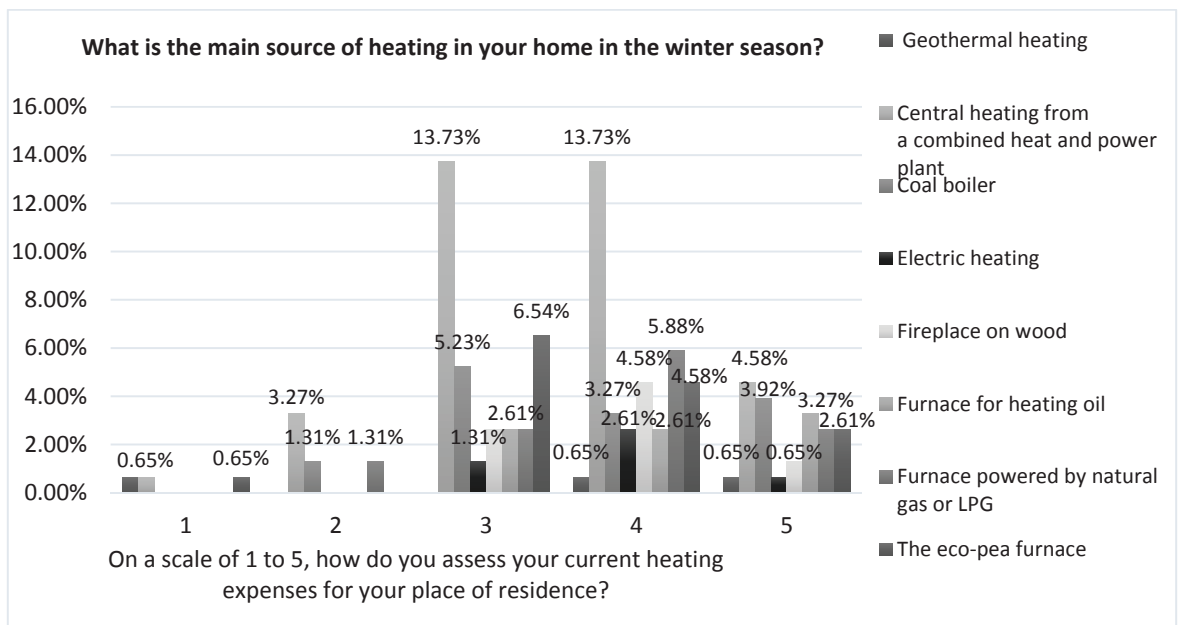

S o u r c e : own elaboration. 
According to the data presented in figure 10, among the respondents $41.18 \%$ consider changing the current heating system in their place of residence. This group consists primarily of residents of single-family homes (55.56\%). A smaller proportion are the residents of blocks (23.80\%) and tenement houses (20.64\%). In case of those unwilling to change, the majority are people living in blocks of flats / skyscrapers (which is understandable due to the possibility of introducing modifications). Analyzing the responses by place of residence, it can be seen that $61.91 \%$ of tenement dwellers are considering changing the heating source, $47.3 \%$ of single-family dwellers and $25.86 \%$ of people living in blocks of flats / skyscrapers.

Figure 10. Frequencies of answers to question 5 depending on the place of residence

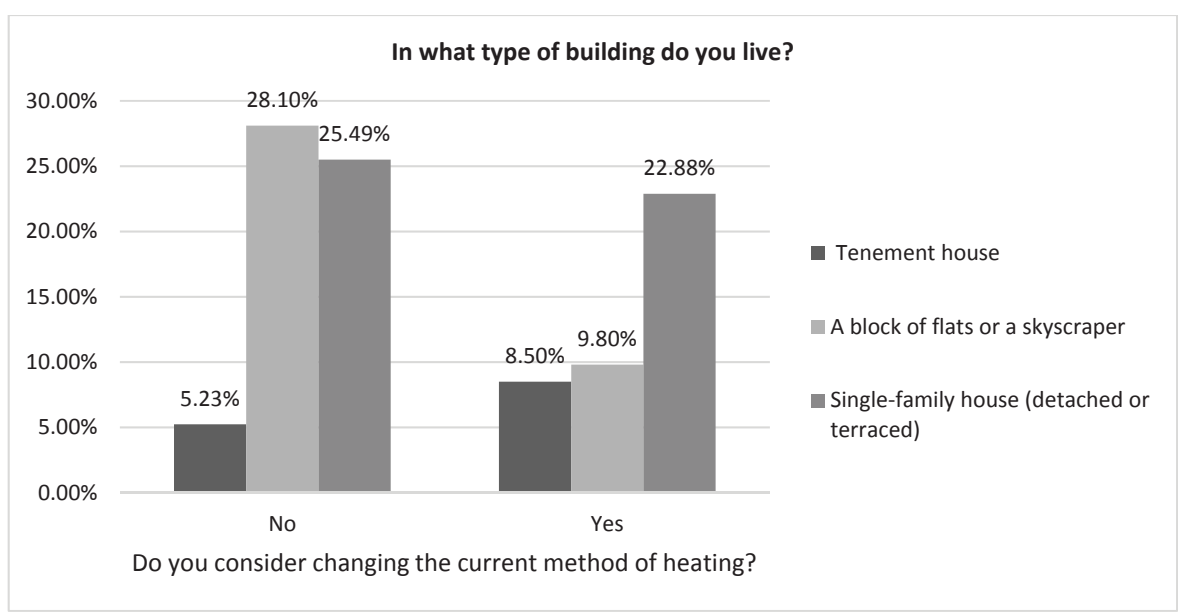

S o u r c e : own elaboration.

The most numerous group considering changing the current source of heating are owners of wood-burning fireplaces $-76.94 \%$ of them declare the will to change. The second place is occupied by people with fuel oil furnaces $-61.53 \%$, and third persons with coal boilers $-52.37 \%$. It is worth noting in this place that only about half of the non-organic, but relatively cheap owners in the purchase of coal-fired boilers declare their willingness to replace them and replace them with an alternative source of heat (figure 11). 
Figure 11. Frequencies of answers to question 5 depending on the heating source

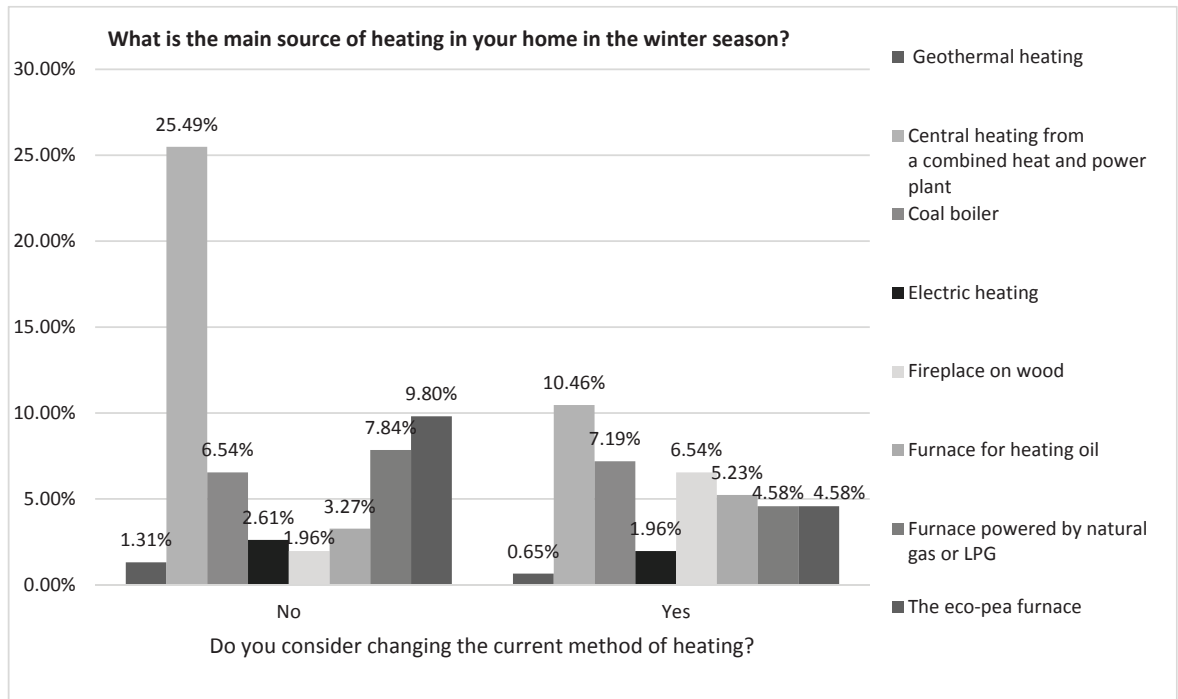

S o u r c e : own elaboration.

Figure 12. Frequencies of answers to question 6 depending on the place of residence



S o u r c e : own elaboration. 
From among respondents, the vast majority (about 67.98\%) expressed their readiness to allocate a larger sum of money to a source of heat, which would differ only in additional ecological benefits. Similar proportions occurred irrespective of the person's place of residence. Inhabitants of single-family homes responded affirmatively in $66.21 \%$ of cases, residents of apartment buildings in $76.18 \%$ (in this case, however, it is a relatively small sample, compared to the total number of respondents), and residents of blocks and high-rise buildings in $67.24 \%$. It is also worth noting that the structure of persons who answered in the affirmative as well as negative, because of their place of residence, does not differ significantly from the structure of all surveyed people presented more quickly on figure 1 . In case of a negative response, it amounts to $38.78 \%$ - residents of blocks, $51.01 \%$ - dwellers of houses, $10.21 \%$ - dwellers of tenement houses, and for the affirmative answer it was $37.50 \%, 47.12 \%$ and $15.39 \%$, respectively. Deviations from the general structure do not reach more than around 5\%. It can therefore be suspected that the place of residence does not significantly affect the individual's approach to the problems of air pollution associated with the combustion of fuels for the purpose of heating homes.

Figure 13. Frequencies of answers to question 6 depending on the heating source

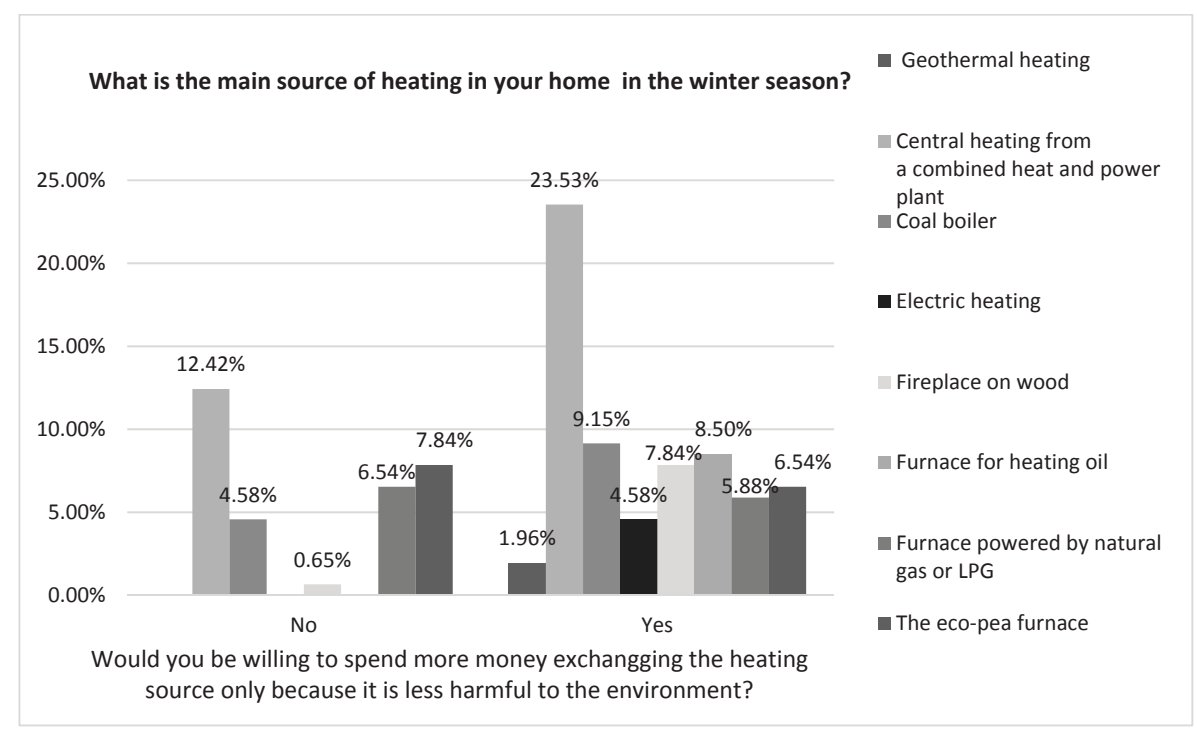

S o u r c e : own elaboration. 
The respondents who answered question 6 in question 6 were representing users of all types of heating sources. From the point of view of the analysis of the next question, it is worth emphasizing that about $5 \%$ of people using coalfired boilers or wood-burning fireplaces were negative. A negative answer was also given by over half of the owners of eco-pea coal furnaces and gas-fired furnaces. This group is made up of people who are mainly driven by economic considerations, but they have already modernized. From the point of view of reducing pollution in the future, the most important group is about $5 \%$, still having obsolete heating sources, and categorically refusing to allocate any additional funds solely for ecology.

People who declared willingness to allocate more funds for additional ecological qualities of the purchased furnace were asked a question, consisting in determining in the range how much money they are willing to earmark for such a purpose. The answers received for this question are presented in figure 14 .

Figure 14. Frequencies of answers to question 7 depending on the place of residence

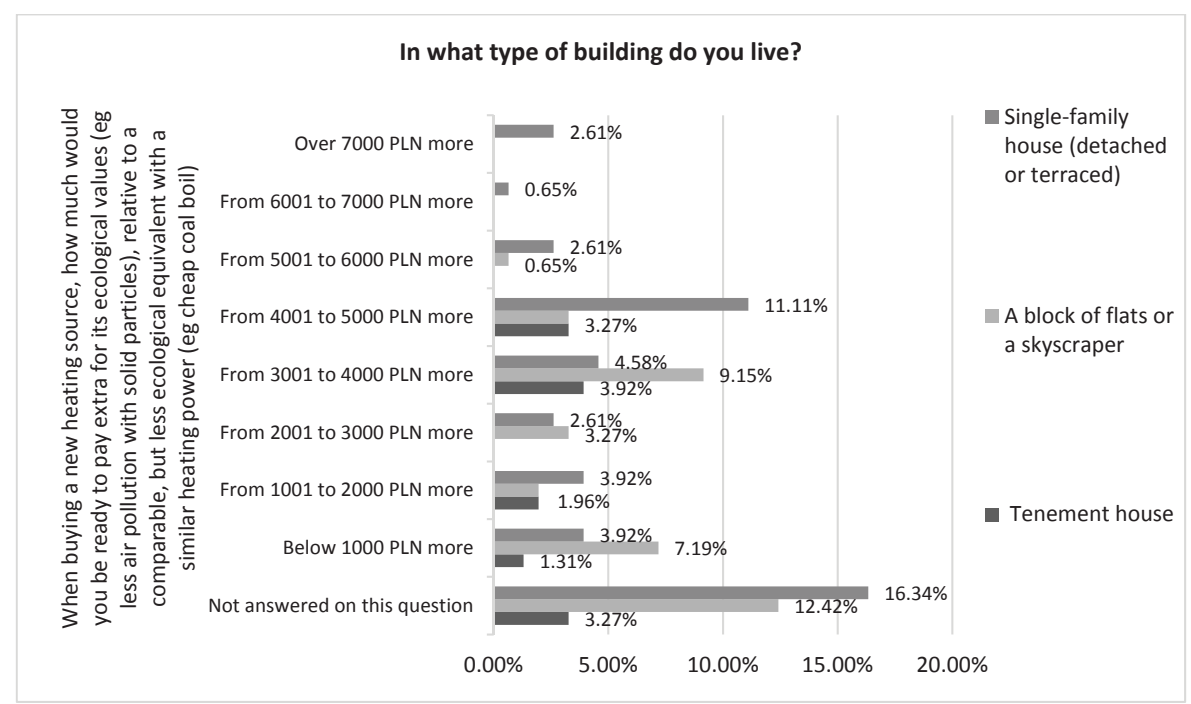

S o u r c e : own elaboration. 
Figure 15. Frequencies of answers to question 7 depending on the heating source

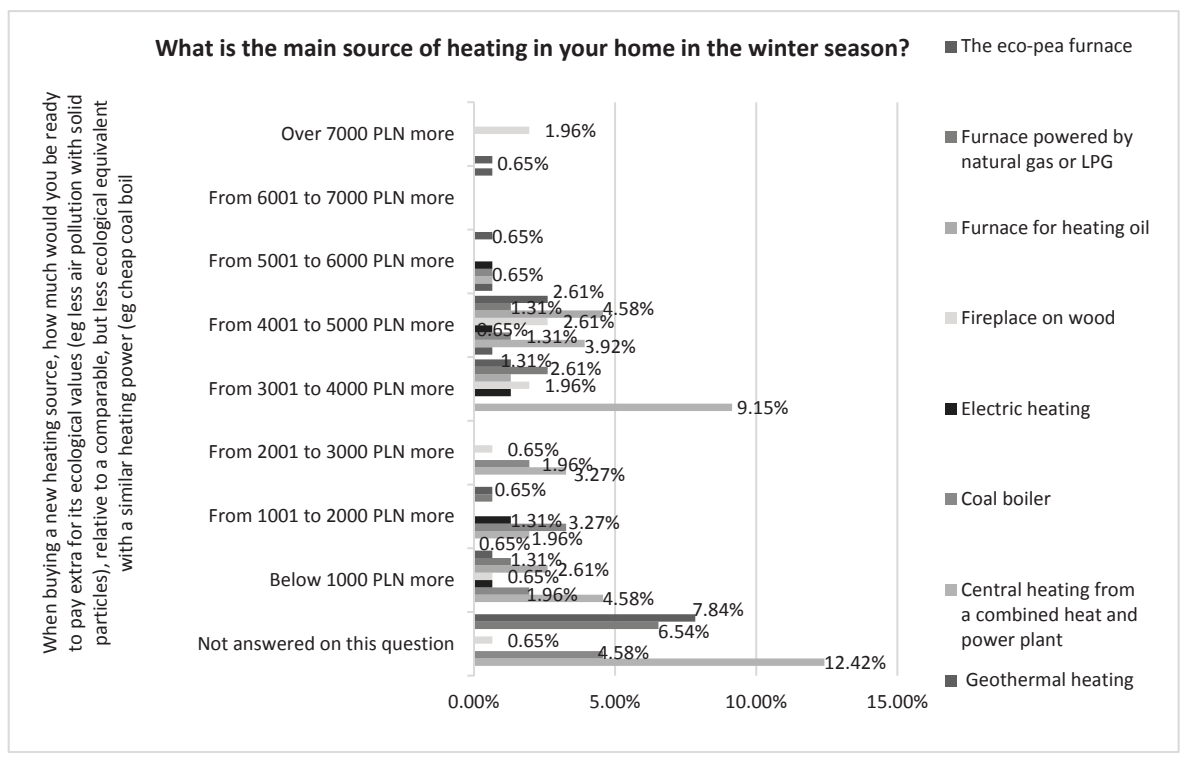

S o u r c e : own elaboration.

The first set of bars, from the bottom of the figure, without a description, presents the distribution of places of residence of people who negatively answered the previous question and therefore did not give any answer in question 7. The percentage division is in this case the same as the one discussed at figure 12. In case people willing to spend additional funds, constituting a group of 104 respondents, the most common answer is between 4 and 5 thousand. Golden. The range between 3 and 4 thousand turned out to be slightly less popular. Golden. With the increase in the amount above 5,000 the number of people ready to incur such significant expenses is drastically decreasing. In the analyzed research sample, about $12.5 \%$ of respondents declared their readiness to use less than PLN 1,000, which in practice means that they are not able to implement ecological investments in their homes in practice, because it is too small to allow the purchase of really friendlier ones. solution environment.

Analysing the figure, it can also be seen that there are clearly more people able to spend in single-family houses, which may be due to the higher level of affluence of such people or greater awareness resulting from the need to heat their own home. For none of the presented response intervals, the ratio simi- 
lar to the initial structure of the place of residence of the general respondents is not kept.

Responses to the question asked by respondents may also be presented depending on the heating source they have in accordance with figure 15.

As in case of the division into the place of residence, the lowest category presents the structure of heating sources for people who do not wish to spend an additional sum of money on the increased ecological values of the heating source. This group was discussed in the analysis of figure 13 , so this section will not be discussed in more detail.

Looking at the incidence rates of individual heating sources for specific response intervals, it is difficult to notice any clear trend. One can risk a statement that people using central heating dominate in lower ranges, while higher compartments are the domain of other heating sources. In addition, it can also be noted that the lower the range, the more predominant the less ecological solutions, such as coal boilers. Such a distribution of responses may be related to the economic situation of the given groups of respondents. Because of their funds, they may be more reluctant to incur unnecessary additional expenses. However, these dependencies should be verified in detail in the further part of the analysis.

154 people participated in the survey, of which $39.22 \%$ were male and $60.78 \%$ were women. The age of the respondents was varied, and the largest group were people aged 21-25, the next age groups show a sharp decline, up to the age range of people aged 31-35. Then the numbers gradually increase, reaching the local maximum for the age of 56-60 years. These dependencies are depicted in figure 16.

Figure 16. Frequency of answers to question 9

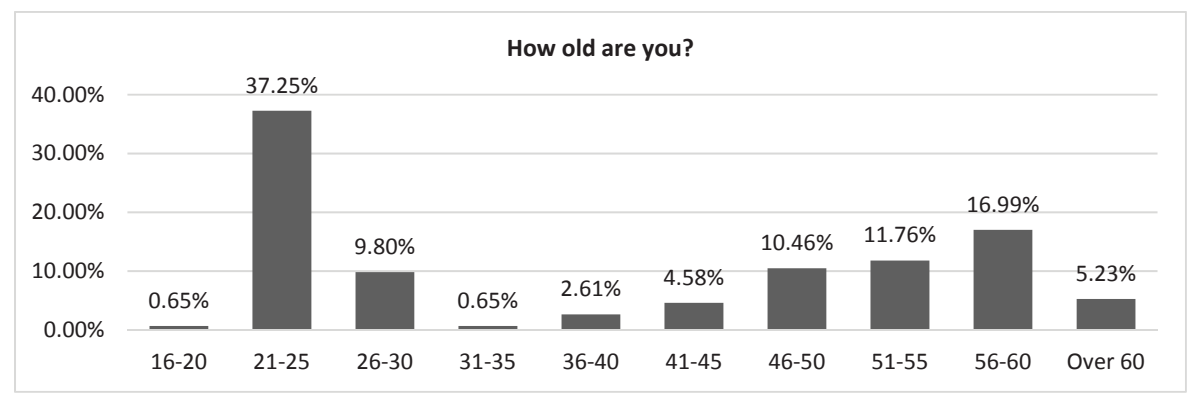

S o u r c e : own elaboration. 
The education of the surveyed people ranged from the upper to the medium one to the professional one. People with higher education accounted for $60.13 \%$, and $35.95 \%$ had secondary education, and $3.92 \%$ had vocational education.

Figure 17. Frequency of answers to question 11

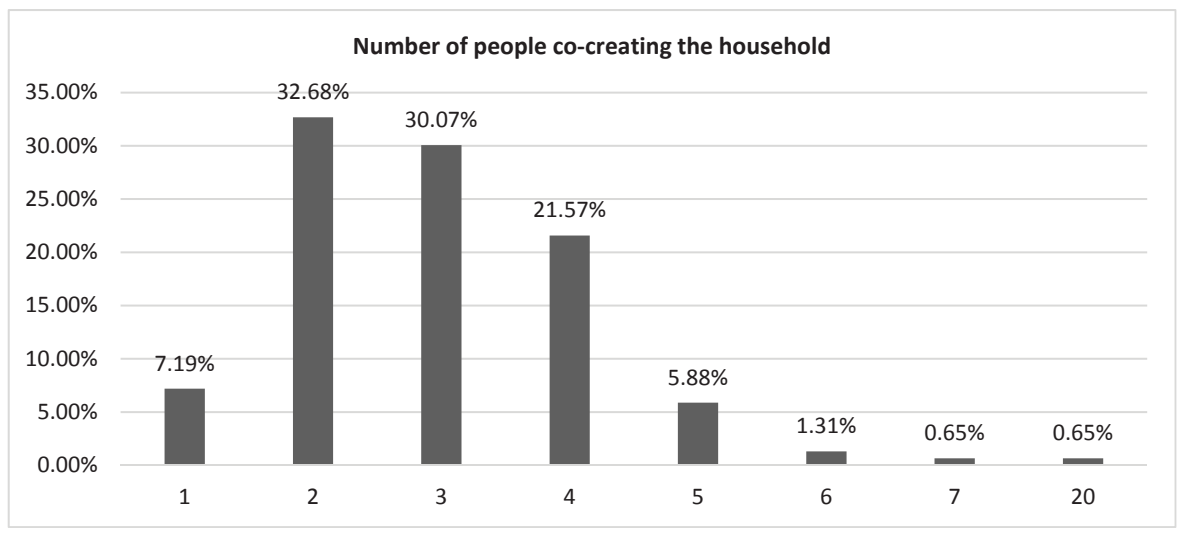

S o u r c e : own elaboration.

In case of the number of people co-creating households, respondents dominate two- and three-person households, as shown in figure 17. Slightly fewer were households made up of 4 people. The remaining variants are characterized by marginal numbers. However, there is a clear right-side obliquity present in this question.

The income of the respondents was on average relatively high, moreover, the largest group constituting over $30 \%$ of respondents were people earning an average of over PLN 3,000 per head in a household. The second most popular income ranges from 1501 to 2000 PLN and from 2501 to 3000 PLN. This distribution is shown in figure 18. 
Figure 18. Frequencies of answers to question 12



S o u r c e : own elaboration.

The survey was addressed mainly to the residents of the two largest cities of the Kuyavian-Pomeranian Voivodeship - Bydgoszcz and Toruń, and their neighborhoods, and therefore, according to conjecture, the largest proportion of respondents are people residing in the countryside and in a city of 200,000 to 500,000 . residents. The remaining types of towns constitute a much smaller percentage, which is shown in figure 19. 
Figure 19. Frequencies of answers to question 13

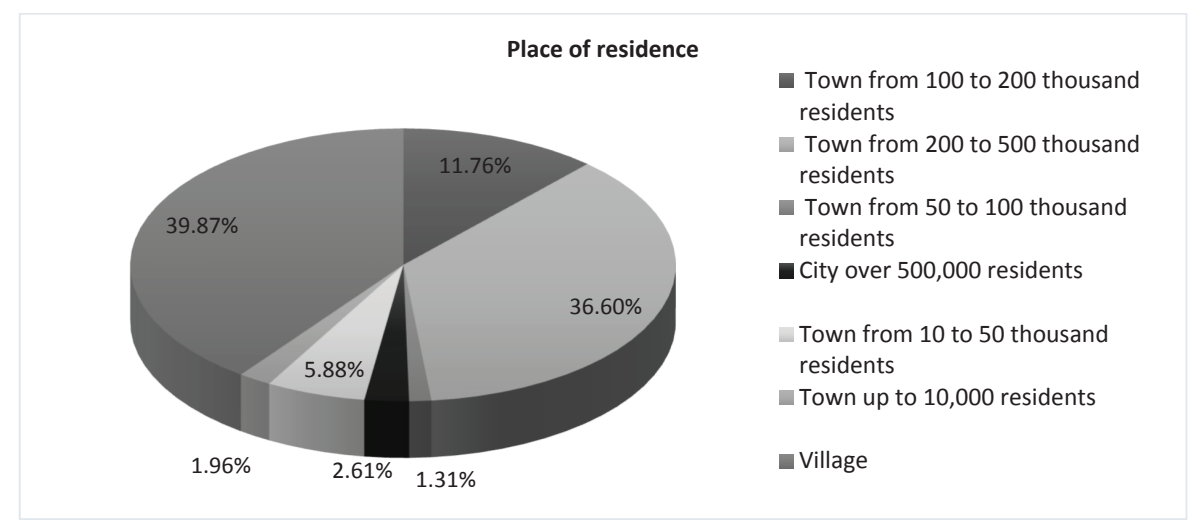

S o u r c e : own elaboration.

The results obtained from the questionnaire in case of questions from 3 to 13 can be analyzed using the correlation analysis between individual answers, giving the appropriate rank given by the respondents to the answers. The information thus processed was then used to calculate the Spearman rank correlation coefficient. The results of the calculations are summarized in table 2 . 


\begin{tabular}{|c|c|c|c|c|c|c|c|c|c|c|c|c|c|c|c|c|}
\hline \multirow{13}{*}{ 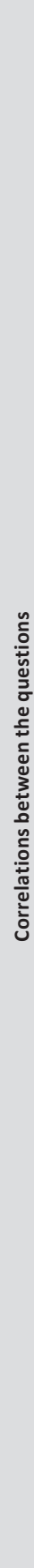 } & $\stackrel{m}{\stackrel{0}{0}}$ & 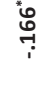 & ণ & $\stackrel{n}{\text { n }}$ & $\stackrel{0}{0}$ & $\stackrel{8}{\&}$ & ભึ & $\stackrel{0}{0}$ & $\overrightarrow{7}$ & $\stackrel{n}{\text { ก }}$ & $\tilde{\tilde{\sigma}}$ & $\stackrel{\infty}{\stackrel{\infty}{\Gamma}}$ & $\stackrel{n}{\text { n }}$ & $\underset{7}{\dddot{7}}$ & $\stackrel{\infty}{\sim}$ & 옴 \\
\hline & $\begin{array}{l}\text { I } \\
\text { ช }\end{array}$ & $\stackrel{\circ}{7}$ & คे & $\stackrel{n}{n}$ & 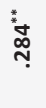 & ঃे & ભึ & : & ঃి & $\stackrel{n}{n}$ & $\stackrel{*}{m}$ & ৪. & $\stackrel{n}{\text { }}$ & $\begin{array}{l}\infty \\
\stackrel{\infty}{\infty} \\
f\end{array}$ & ঃे & ণ \\
\hline & $\begin{array}{l}\overrightarrow{7} \\
\dot{0}\end{array}$ & $\stackrel{m}{0}$ & กิ & $\stackrel{\mathscr{H}}{\sim}$ & $\stackrel{\infty}{\underset{7}{7}}$ & $\stackrel{\text { そq }}{\neg}$ & ભึ & Oे & 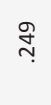 & $\stackrel{n}{\Omega}$ & $\stackrel{\mathscr{0}}{0}$ & 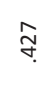 & 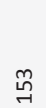 & $\begin{array}{l}\mathscr{N} \\
0 \\
0\end{array}$ & $\stackrel{n}{\stackrel{n}{r}}$ & ণ \\
\hline & $\begin{array}{l}\text { 웅 } \\
\text { 엉 }\end{array}$ & o̊ & $\begin{array}{l}0 \\
\sigma \\
\sigma\end{array}$ & $\stackrel{n}{ٌ}$ & "ָ̣: & $\vec{\sigma}$ & $\stackrel{n}{\stackrel{n}{n}}$ & $\stackrel{*}{\stackrel{*}{\sim}}$ & ঃ & $\stackrel{n}{\stackrel{n}{\sim}}$ & શి & $\stackrel{\Delta}{0}$ & $\stackrel{n}{\stackrel{n}{\sim}}$ & 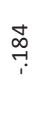 & $\vec{\emptyset}$ & ذ্ণ \\
\hline & $\begin{array}{l}\dot{\sigma} \\
\dot{\sigma}\end{array}$ & $\stackrel{*}{\stackrel{*}{*}}$ & ஜे & $\stackrel{n}{\sim}$ & సै & ঃ & $\stackrel{n}{\leftrightarrow}$ & 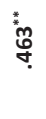 & ঃ & $\stackrel{n}{\stackrel{n}{\sim}}$ & $\stackrel{*}{\stackrel{*}{\mathbf{N}}}$ & ö & $\stackrel{\mathscr{n}}{\sim}$ & $\stackrel{*}{\stackrel{*}{0}}$ & ঃ & 옴 \\
\hline & ó & $\stackrel{\stackrel{n}{\tilde{m}}}{0}$ & $\stackrel{\mathscr{N}}{N}$ & ఫ્ન & : & $\overrightarrow{8}$ & $\underset{-}{\stackrel{+}{+}}$ & $\stackrel{*}{\tilde{m}}$ & ৪ & ণ্ণ & & & ષ્ન & $\begin{array}{l}8 \\
\stackrel{-}{-}\end{array}$ & & ષ્ণ \\
\hline & $\begin{array}{l}0 \\
\dot{\sigma}\end{array}$ & $\begin{array}{l}\infty \\
\stackrel{\infty}{0}\end{array}$ & $\underset{m}{m}$ & $\stackrel{n}{\stackrel{n}{\sim}}$ & $\underset{-1}{\mathbb{T}}$ & $\stackrel{\text { ֻn }}{0}$ &  & 宽 & ঃ & $\stackrel{n}{\Omega}$ & $\begin{array}{l}\stackrel{8}{0} \\
\text { o }\end{array}$ & $\cdot$ & $\stackrel{n}{\stackrel{n}{n}}$ & . & & 옥 \\
\hline & $\stackrel{\text { ñ }}{\dot{\sigma}}$ & $\stackrel{*}{\tilde{N}}$ & 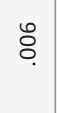 & $\stackrel{n}{ٌ}$ & 党 & ঃ & ભึ & $\begin{array}{l}\stackrel{8}{\circ} \\
\text { ¿ }\end{array}$ & & $\stackrel{n}{\sim}$ & : & ঃ & $\stackrel{n}{ٌ}$ & $\vec{y}$ & ঃ & ذ્ન \\
\hline & $\dot{\sigma}$ & స్ํำ & ঃ & $\stackrel{n}{ٌ}$ & $\begin{array}{l}8 \\
\stackrel{0}{ } \\
-i\end{array}$ & & ભึ &  & ঃ & $\stackrel{\Re}{\stackrel{్}{్}}$ & త్ర & 导 & $\stackrel{\mathscr{్}}{\sim}$ & 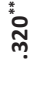 & ¿- & ఫ্ન \\
\hline & $\stackrel{m}{\dot{\sigma}}$ & 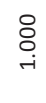 & e & $\stackrel{n}{\neg}$ & స్․․ & ঃ & Щี & $\stackrel{n}{\sim} \stackrel{*}{N}$ & ஜ & $\stackrel{n}{n}$ & $\begin{array}{l}\stackrel{0}{0} \\
0\end{array}$ & $\stackrel{m}{\tilde{m}}$ & $\stackrel{n}{\neg}$ & $\stackrel{n}{\tilde{O}}$ & $\stackrel{\mathscr{N}}{N}$ & 욱 \\
\hline & & 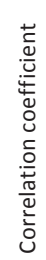 & 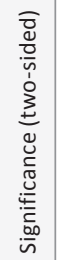 & $z$ & 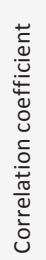 &  & $z$ & 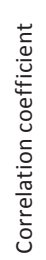 & 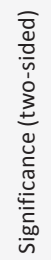 & $z$ & 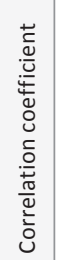 & 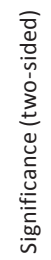 & $z$ &  & 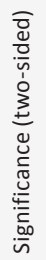 & $z$ \\
\hline & & $\stackrel{m}{\sigma}$ & & & $\begin{array}{l}\dot{\sigma} \\
\dot{\sigma}\end{array}$ & & & $\begin{array}{l}\tilde{u} \\
\dot{\sigma}\end{array}$ & & & $\begin{array}{l}0 \\
0\end{array}$ & & & $\hat{\sigma}$ & & \\
\hline & & 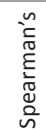 & & & & & & & & & & & & & & \\
\hline
\end{tabular}


11. THE TENDENCY OF HOUSEHOLDS TO INVEST...

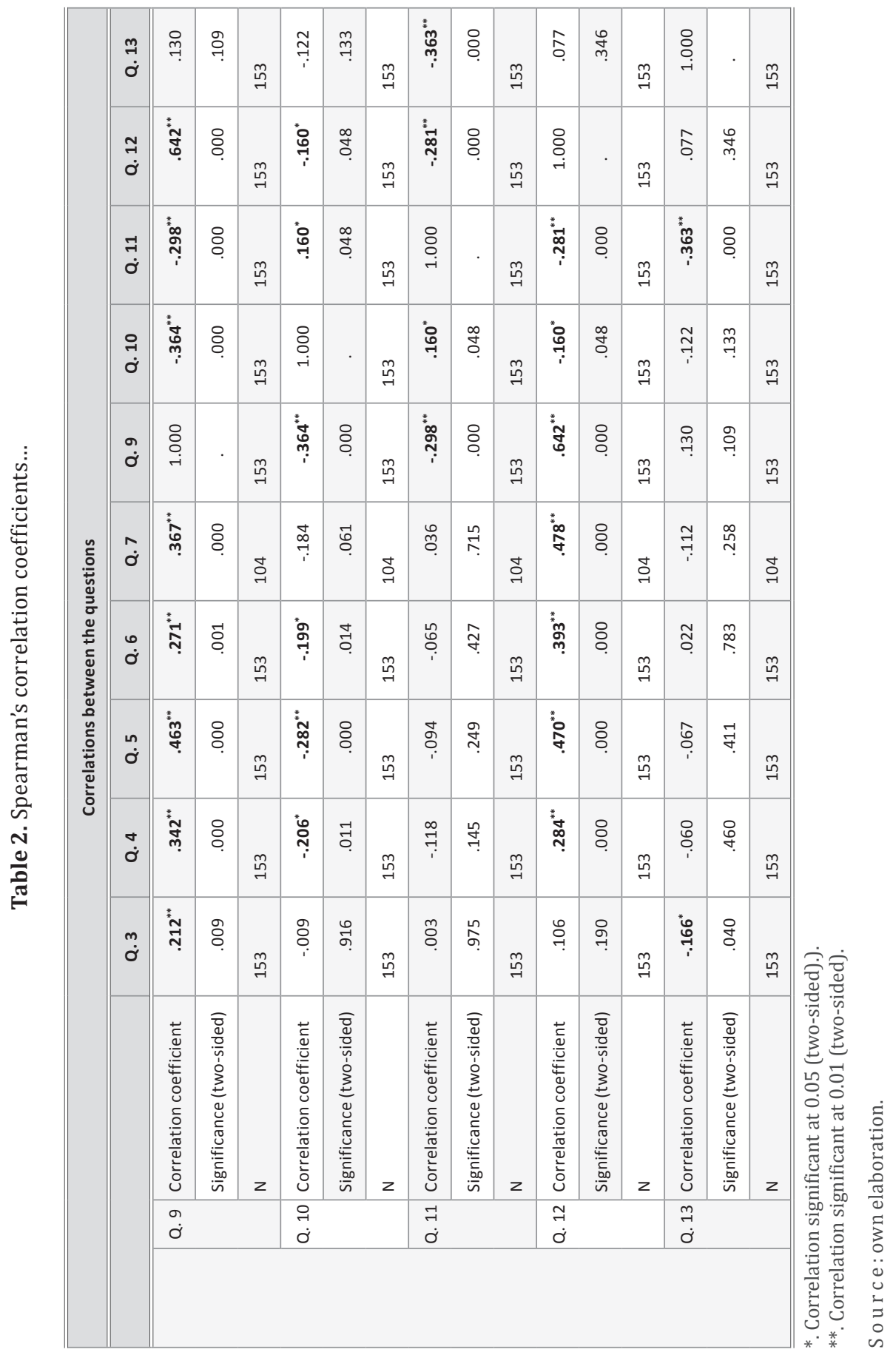


According to the obtained results of Spearman's correlation coefficients, a significant correlation at the $1 \%$ significance level can be observed between the weight that the surveyed person attaches to heating expenses and the level at which he assesses the amount of expenditure incurred. It can therefore be noted that people who declare that they pay more attention to the heating costs they incur more often regard their expenses as higher.

An important correlation can also be noticed between the importance attached to expenditure (question 3) and the sense of the amount of costs generated by the heating system used (question 4) and the declared willingness to readiness to change the current heating system (question 5). This correlation is economically justified, because in a situation when a given person thinks that he or she incurs excessive costs and pays considerable attention to them, sooner or later he / she will start looking for solutions that would enable them to lower them.

In case of the question about the readiness of the respondent to incur higher expenses by the respondent for a new source of heating due to its ecological values (question 6), the answers provided (similarly as in the other cases discussed so far) show a significant correlation at the level of $1 \%$ of significance with the fact whether the person is considering or not considering changing the heat source. It is also worth noting that at a significance level equal to $5 \%$, the correlation between the answers given to the said question 6 and the respondent's level of heating spending is also significant.

Similar behaviour of indicators was observed for question pairs 4 and 7 and 5 and 7. In this case, however, the calculated values for both pairs are significant at the $1 \%$ significance level. It can therefore be stated that the respondents, convinced of incurring too high heating costs, as well as declaring their willingness to replace the current heating system, more often declared higher amounts that they are willing to invest in modernizing furnaces.

In the sample examined, age played a very important factor showing links with almost all issues raised in the questionnaire. Correlation coefficients are relevant to all questions except question 13 on the size of the town where the respondent lives. In other cases, it can be concluded that there are positive relationships between age and perception of expenditure, sense of their significance in the budget, readiness to change the heating system, the sum the respondent is willing to allocate for this purpose, and average income per member of the household. These dependencies may be justified, as with age people generally increase their earnings, possessions, and pay more attention 
to expenses incurred. However, negative correlations can be noticed between the age of the respondent and education and the number of people co-creating the household. The reason for the occurrence of the first is probably the lower popularity of studying in the last century, when secondary or technical education was higher than higher. The number of people co-creating the household along with the respondent's age may decrease due to the gradual removal of the raised children after they reach a mature age.

The education of the surveyed persons (question 10) shows a negative correlation to the declared willingness to change the heating method (question 5), the desire to add extra money in exchange for increased ecological values (question 6), as well as the feeling of being burdened with heating expenses (question 4). Nevertheless, it should be noted that the observed relationships are much weaker than those discussed earlier, because their significance reaches only $5 \%$ (except for question 5 , for which the significance is $1 \%$ ). In addition, the education of respondents shows a weak positive correlation (0.160), significant at $5 \%$ with the number of people forming a household.

The average income per capita in the respondents' households is characterized by a significant correlation with almost all other responses provided in the questionnaire (except for question 3 about how much attention the respondent draws on expenses for heating and question 13 about the place of residence of the examined person). Other areas related to the feeling of spending, willingness to modernize, readiness to devote additional funds to this purpose, as well as the age of the respondent, show a significant $1 \%$ positive correlation ranging from 0.284 to even 0.642 . In case of the level of education and the number of household members, a negative correlation of -0.160 (for the level of significance of 5\%) and -0.281 (for the significance level of $1 \%$ ) can be observed. It can be concluded on this basis that a very strong relationship with the decisions made regarding heating expenses and the problem of ecology of the heat sources used has the level of a person's income. This means that for respondents in this type of election over ecology, above all the economic aspect is what matters, and ecology is not necessarily treated as a superior value.

The size of the place of residence does not show too many correlation links with other questions raised in the survey. A weak negative correlation was obtained for question 3 and stronger (on the significance level of 1\%) - for the question regarding the number of household members. 
Chi-square tests can not be used for the obtained data, because for individual pairs of questions, the number of expected cells is less than 5 in over $20 \%$ of them, which excludes the possibility of reliable results for this test. Combining the response intervals for most questions is not possible due to their nature, and as a result of the study, no more completed questionnaire forms were obtained. For this reason, correlation analysis has been limited only to Spearman's correlation coefficient. For example, in tables 3 and 4, the results of the chi-square test for exemplary two pairs of questions were included.

Table 3. Chi-square test results for questions 7 and 12

\begin{tabular}{|l|c|c|c|}
\hline \hline \multicolumn{4}{|c|}{ Chi-square test } \\
\hline \hline & Value & df & Asymptotic significance (two-sided) \\
\hline \hline Pearson's chi-square & $89.730^{\mathrm{a}}$ & 42 & .000 \\
\hline Likelihood ratio & 91.906 & 42 & .000 \\
\hline Linear dependence test & 20.624 & 1 & .000 \\
\hline N number of significant observations & 104 & & \\
\hline \hline
\end{tabular}

a. $91.1 \%$ of cells (51) have expected numbers less than 5 . The minimum expected number is .02 .

S o u r c e : own elaboration.

Table 4. Chi-square test results for questions 4 and 12

\begin{tabular}{|l|c|c|c|}
\hline \hline \multicolumn{4}{|c|}{ Chi-square test } \\
\hline \hline & Value & df & Asymptotic significance (two-sided) \\
\hline \hline Pearson's chi-square & $13.682^{\mathrm{a}}$ & 8 & .090 \\
\hline Likelihood ratio & 15.427 & 8 & .051 \\
\hline Line relationship test & 6.739 & 1 & .009 \\
\hline N number of significant observations & 153 & & \\
\hline \hline
\end{tabular}

a. $53.3 \%$ of cells (8) have expected numbers less than 5 . The minimum expected number is 12 .

S o u r c e : own elaboration.

On the other hand, the collected results can also be analysed by Cronbach's alpha test, the results of which are presented in table 5 . 
Table 5. Cronbach's alpha test

\begin{tabular}{|c|c|c|c|c|c|}
\hline \multicolumn{3}{|c|}{ Reliability statistics } & & & \\
\hline Cronbach's alpha & \multicolumn{2}{|c|}{ number of positions } & & & \\
\hline \multirow{2}{*}{\multicolumn{2}{|c|}{.614}} & 5 & & & \\
\hline & & $\begin{array}{l}\text { The average } \\
\text { of the scale } \\
\text { after removing } \\
\text { the item }\end{array}$ & $\begin{array}{l}\text { Scale variance } \\
\text { after removing } \\
\text { the item }\end{array}$ & $\begin{array}{l}\text { Correlation } \\
\text { of positions } \\
\text { Total }\end{array}$ & $\begin{array}{l}\text { Cronbach's } \\
\text { alpha after } \\
\text { removing } \\
\text { the item }\end{array}$ \\
\hline \multicolumn{2}{|c|}{$\begin{array}{l}\text { On a scale of } 1 \text { to } 5 \text {, how much attention } \\
\text { do you pay for heating expenses? }\end{array}$} & 13.58 & 13.101 & .194 & .629 \\
\hline \multicolumn{2}{|c|}{$\begin{array}{l}\text { On a scale of } 1 \text { to } 5 \text {, how do you assess } \\
\text { your current heating expenses for your } \\
\text { place of residence? }\end{array}$} & 13.82 & 11.277 & .446 & .536 \\
\hline \multicolumn{2}{|c|}{$\begin{array}{l}\text { Do you consider changing the current } \\
\text { method of heating? }\end{array}$} & 17.02 & 12.602 & .626 & .549 \\
\hline \multicolumn{2}{|c|}{$\begin{array}{l}\text { When buying a new heating source, } \\
\text { how much would you be ready to pay } \\
\text { extra for its ecological values (eg less air } \\
\text { pollution with solid particles), relative to } \\
\text { a comparable, but less ecological equ- } \\
\text { ivalent with a similar heating power (eg } \\
\text { cheap coal boiler)? }\end{array}$} & 13.91 & 7.653 & .413 & .568 \\
\hline \multicolumn{2}{|c|}{$\begin{array}{l}\text { Average income per person in a house- } \\
\text { hold }\end{array}$} & 12.02 & 8.213 & .484 & .492 \\
\hline
\end{tabular}

S o u r c e : own elaboration.

The Cronbach's alpha factor for the presented pool of questions, assessing the perception of the necessity to incur financial expenses for environmental protection, is at the level of 0.614 , which indicates a moderate reliability of the conducted test. It is worth noting, however, that in this case the obtained results may be characterized by a relatively high error as a result of a significant reduction of the sample range, reaching only $68 \%$ of the sample, which is presented in table 6 . An additional effect on the Cronbach's alpha test result is certainly a relatively small amount questions examining a particular behaviour or characteristic. The presented question in table 5 relate to the tendency to bear outlays on ecology and the awareness of the respondents about the necessity of incurring such expenses in the interest of the natural environment in a relatively broad sense. 
Table 6. Information about the analysed data

\begin{tabular}{|c|c|c|c|}
\hline & & $\mathbf{N}$ & $\%$ \\
\hline \multirow[t]{3}{*}{ Observations } & Significant & 104 & 68.0 \\
\hline & Excluded $^{a}$ & 49 & 32.0 \\
\hline & Total & 153 & 100.0 \\
\hline
\end{tabular}

a. Removal of observations due to all variables in the analysis.

S o u r c e : own elaboration.

\section{CONCLUSION}

The decision, making process to modernize the heating source used in the household is a complex process. Similarly, as in case of all investment decisions, its result is influenced by many factors, both economic and moral, and the sense of responsibility for the surrounding nature is also important.

Among the participants of the study, slightly less than half expressed in the present conditions the desire to modernize the heat source being used, and in the negative group the majority did not use outdated and the most environmentally harmful coal boilers or wood-burning fireplaces or fuel oil stoves.

Based on the results of the study, it can be noted that ecology for about $2 / 3$ of respondents is not indifferent, because more or less such a percentage declares readiness to incur additional expenses only to increase ecological values of the investment object. Problems begin when estimating how high these people value the value of ecological solutions. It turns out that a large part of the respondents (about 18\% of those who declare the will to incur additional expenditure on ecology) are ready to allocate modest amounts (up to a thousand zlotys) that can not really translate into a real increase in the environmental parameters of the purchased device, even taking into account current levels of funding on the part of local governments. This group of theoretically questionnaires is ready to allocate some funds for ecology, but it requires almost equalling the costs of purchasing greener solutions with the purchase costs of alternative, cheapest available forms of heating on the market.

In assessing the value of a heating source for a potential buyer, economic advantages play a key role in a large group of respondents. Correlation analysis of the received responses showed very important links between the level of average earnings, the sense of the burden of heating expenses for the place of residence, and the amount the person is willing to spend on additional ecologi- 
cal qualities of the modernized heating source. The significance of economic aspects is also confirmed by the lack of correlation between the level of declared additional expenses for ecological benefits and the level of education of the surveyed person. Among the potential non-financial factors, only age showed some correlation with declared additional expenses. However, it may be due to the fact that people over the years receive higher income (which is confirmed by a very strong correlation at the level of 0.642 between age and average income per capita in a household), and increased income is already an economic factor.

Due to the dominance of economic factors, in order to guarantee the improvement of the quality of air in cities being the subject of the study, currently adopted programs co-financing the modernization of obsolete heating sources can be considered as an appropriate and effective action. Nevertheless, in order to ensure complete elimination of harmful furnaces, due to the declared amounts by some of the respondents, one should strive to reduce the price of ecological solutions or introduce regulations that would further reduce the price difference between ecological and traditional - more harmful solutions.

\section{REFERENCES}

Budzynski, W., \& Bielski, S. (2006). Agricultural raw materials of agricultural origin, Part II. Biomass as solid fuel. Acta Scientiarum Polonorum. Agricultura, 3(2), 15-26.

Kaczmarczyk, M. (Ed.) (2015). Low emission - from the reasons for occurrence to the elimination methods. Krakow: GLOBEnergia.

Lesniak, W., Janczar-Smuga, M., Podgorski, W., \& Klinkowski, M. (2012). Heat pumps - an ecological source renewable energy. Acta Scientiarum Polonorum. Agricultura, 3(6), 78-89.

Mikłaszewski, A. (2017). Low emission and its impact on health. Wrocław: Lower Silesian Ecological Club.

Morris, C., \& Pehnt, M. (2017). German energy transformation - the future based on renewable energy sources. Berlin: Heinrich Böll Stiftung.

Nowak, T., \& Kowalczyk, J. (2015). Magnetic fields of permanent magnets as an effective source of organic thermal energy production. Electronics: constructions, technologies, applications, 56(9), 100-101.

(www1) Greenpeace: facebook, http://www.facebook.com/greenpeacepl/videos/1948557418785597 (accessed: 27.01.2019).

(www2) Misja - emisja, http://misja-emisja.pl/knowledgebase/wdychamy-gdy-spalamy-wegiel-biomase (accessed: 27.01.2019).

(www3) Business Insider Polska, http://businessinsider.com.pl/rozwoj-osobisty/zdrowie/jak-chiny-walcza-ze-smogiem/k2r1bz1 (accessed: 28.01.2019). 
(www4) Miasto Bydgoszcz, http://www.bydgoszcz.pl/rozwoj/srodowisko/powietrze/ dotacja-na-wymiane-ogrzewania-program-ekopiec-2018 (accessed: 29.01.2019).

(www5) Miasto Toruń, http://www.torun.pl/pl/dotacje-na-wymiane-piecow (accessed: 29.01.2019).

(www6) Ekologia, http://www.ekologia.pl/srodowisko/ochrona-srodowiska/smogczy-rzeczywiscie-jest-taki-grozny,22433.html (accessed: 27.01.2019). 